\title{
Problems and Prospects of Potato Cultivation in Bangladesh
}

\author{
Muktasha Deena Chowdhury ${ }^{1}$, Anupam Hayath Chowdhury ${ }^{2}$
}

${ }^{1}$ Lecturer, Statistics, Asian University of Bangladesh, BANGLADESH

${ }^{2}$ Lecturer, Mathematics, Asian University of Bangladesh, BANGLADESH

\begin{abstract}
Bangladesh is predominantly an agricultural country. Agriculture is the indispensable culture of Bangladesh. Agriculture has an enceinte contribution to the Gross Domestic Product (GDP) of the country. Earlier more than $50 \%$ of GDP came from this sector. Various types of crops are produced in this country. These crops can be categorized into two; food crops and cash crops. Potato is one of the food-stuff of the most people of the world as well as Bangladesh. Potato crop is being treated as foremost crop. This research was conducted to find out the problems that the farmers face in cultivation and to study the trend of production of potato and relationship between production and export of potato of Bangladesh. The study also aims to show the estimates of potato per division in Bangladesh and thus to help in showing its prospects. This research is quantitative in nature. Data collected from both primary and secondary data sources. Primary data collected from 50 farmers using convenience sampling technique with a set of questionnaires designed for this study. Secondary data is obtained from secondary data sources, Department of Agricultural Extension (DAE) and BBS (Bangladesh Bureau of Statistics). After collecting the data, they were transcribed, tabulated and analysed in terms of the research objectives.
\end{abstract}

Keywords: Potato, Cultivation, Bangladesh

\section{INTRODUCTION}

Cultivated plant Potato, edible tuber of the cultivated plant Solanumtuberosum of the family Solanaceae. It was the major crop for the original Americans. It is now one of the staple foods in Bangladesh. Bangladesh is mainly an agro-based country. It is a thickly populated small country with an area of 14.48 million ha. According to an estimate by Bhuiyan et al., 2002, net cultivable land would decrease from 8.42 million ha in 2000 to 7.89 million ha in 2025 and population would increase from 127.22 million in 2000 to 168.96 million in 2025. The per capita net cultivable land would reduce from 0.066 ha in 2000 to 0.047 ha in 2025 (Bhuiyan et al., 2002). The population has doubled in the last 30 years despite a decline in the annual population growth rate from 2.26 in 1961 to 1.47 in 2004. Potato is a staple food in the developed countries and which accounts for $37 \%$ of the total production in the world (FAO and CIP, 1995). Considering the trend of population growth and consequently the increased demand for food in the country and dwindling cultivable land area, the potato is likely to play a vital role in the future. Potato is a popular and important vegetable in Bangladesh. For the whole year, it is used as the main vegetable. Potato production in Bangladesh in the fiscal year (FY) 2012-2013, hit a new record of 8.603 million tonnes surpassing the record of 8.38 million tonnes in FY'11. The production witnessed a negative growth in FY'12 when it plunged to 8.205 million tonnes- a 2.08 percent fall compared to that of FY'11. The Government statistics provider, Bangladesh Bureau of Statistics (BBS) in its latest release, said potato, the most consumed vegetable item of the country was cultivated on .444 million hectares of land in FY'13. The acreage had increased by 14,000 hectares compared to that of FY'12 which also helped achieve a higher output. Potato was produced on 4.6 million hectares in FY'11.Bidhan Baral, deputy director at BBS told the FE that per hectare yield has been increasing gradually in the country which is very positive for the production scenario. On the other hand, potato export saw a quantum leap in the recently concluded fiscal year, buoyed by higher shipments of Russia amid a tight supply from Pakistan and India to the global market. In Bangladesh, exports crossed the one-lakh-tonnes mark for the first time in the fiscal 2013-14, rising threefold from only 28,416 tonnes in the previous year, according to the Department of Agricultural Extension (DAE). Earning also trebled to \$33.82 million in 2013-2014 compared to the previous year, Export Promotion Bureau data shows. This is a milestone. We want to perform better in the days to come. Potato is one of the main commercial crops grown all over the country. In Bangladesh, potato is mainly consumed as a vegetable. Various other food items (Singara, Samucha, Chop, chips etc.) are also made from potato. Adequate supply of potato stabilizes the vegetable market all round the year (Moazzem and Fujita, 2004). Recently, the government has been trying to diversify food habits and encourage potato consumption to reduce pressure on rice. So, potato is becoming an important food for food security in Bangladesh. 


\section{LITERATURE REVIEW}

A number of studies to agronomic, economic and physiological aspects of potato cultivation have so far been conducted in Bangladesh. This study focused on the problems and possible recommendations in potato cultivation and also showed the relationaship between production and export of potato of Bangladesh. Sabur (1988) conducted a study on marketed surplus of potatoes in two districts of Bangladesh, he found that production and marketed surplus of potatoes moved in some positive direction. He observed that the average production cost per hectare was TK. 29635.57 and net return was TK. 30947.82. Das (1992) conducted a study on the profitability of potato cultivation and found that the average yield of potato was $4720 \mathrm{~kg}$ per hectare and the average gross return amounted to TK. 33040 per hectare. Et, al. (2001) conducted a survey on potato production in some selected areas of Bangladesh. This study showed that potato production is highly profitable, and it can provide cash money to farmers. In terms of profitability, potato production was more attractive than any other winter vegetables. Per unit yield and gross return of potato were found higher than other competitive crops. According to Noor-e-Alam Siddique, potato has greater scope and potential for food security and poverty alleviation in Bangladesh.

\section{Objectives of the Study}

Potato plays a vital role to meet the demand of food in Bangladesh and the climate of Bangladesh is favorable for the cultivation of potato. If we increase its production and exportation and ensure its proper utilization it can contribute a lot in the economy of Bangladesh. The objectives of this study are:

- Identify problems and suggest probable solutions for expansion of potato cultivation.

- To find out the prospects of potato cultivation in Bangladesh.

- To find out the trend of the production and export of potato in Bangladesh.

- Identify the relationship between production and export of potato of Bangladesh.

- To find out the reasons for rising the exportation of potatoes.

\section{Methodology}

Both primary and secondary data were used in this study. Primary data was collected from 50 farmers using convenience sampling technique with a set of questionnaires designed for this study. Secondary data was collected from secondary data sources, Department of Agricultural Extension (DAE) and BBS (Bangladesh Bureau of Statistics) etc. will be used for the research. Following statistical analysis will be conducted with the help of statistical applications, such as, SPSS and MS Excel:

- Frequency curve
- Bar Diagram

- Pie Diagram

- Correlation analysis

- Regression analysis

\section{LIMITATION OF THE STUDY}

- The primary data has been collected by convenience sampling for convenience. So we might not get the necessary information.

- Due to the shortage of time the study could not cover wide side areas for collecting necessary information.

- Respondents had no written document. Therefore, the researcher had to depend solely on the memory of the respondents.

\section{Problems in potato cultivation}

From our primary data, we got the following problems in cultivation of potatoes:

- Unavailability of good quality seed

- Lack of adequate funds

- Unavailability of quality fertilizers in time

- Disease infection

- Labor crisis

- Lack of cold storage facilities

- Low prices at peak harvest period

- High cold storage charge

- No purchase by the government

\section{Data Analysis, Findings AND Discussion}

Trend of production of potatoes in Bangladesh

Table 1: Production of potato, 2008-2009 to 2012-2013

\begin{tabular}{|c|c|c|c|c|c|}
\hline Year & $2008-2009$ & $2009-2010$ & $2010-2011$ & $2011-2012$ & $2012-2013$ \\
\hline $\begin{array}{c}\text { Production } \\
\text { (in thousand tons) }\end{array}$ & 5268 & 7930 & 8326 & 8205 & 8603 \\
\hline
\end{tabular}

Source: Statistical Year Book of Bangladesh (2013)

Table 1 shows the production of potato (in thousand tons) in Bangladesh from 2008-2009 to 2012-2013. From the above data, we get the following frequency curve which clearly shows us that production of potato in Bangladesh is increasing rapidly which is very positive for the production scenario.

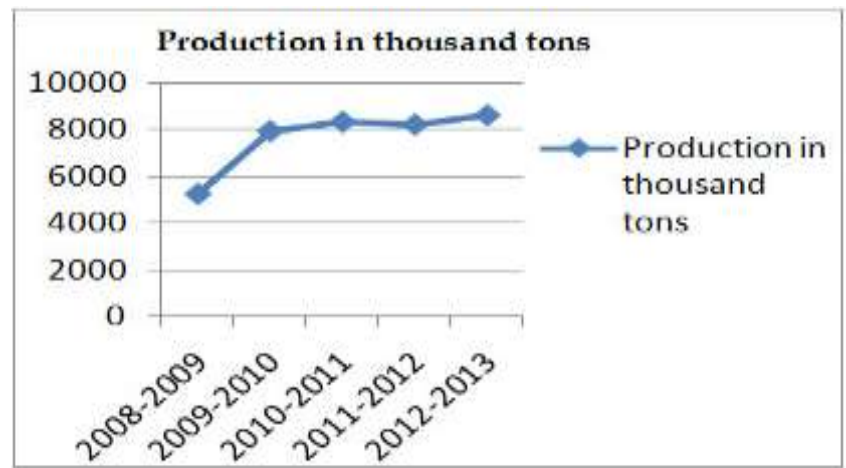

Fig: Production in thousand tons from 2008-2009 to 2012-2013 
Table 2: Annual potato exports, 2007-2008 to 2013-2014

\begin{tabular}{|c|c|c|c|c|c|c|c|}
\hline Year & $2007-$ & $2008-$ & $2009-$ & $2010-$ & $2011-$ & $2012-$ & $2013-$ \\
& 2008 & 2009 & 2010 & 2011 & 2012 & 2013 & 2014 \\
\hline Exports (in & 5.412 & .407 & 9.687 & 39.539 & 18.862 & 28.416 & 103 \\
Thousand tons) & & & & & & & \\
\hline
\end{tabular}

Source: Plant Protection Wing (DAE)

Table 2 shows the high increase in potato exportation in Bangladesh from fiscal year 2007-2008 to 2013-2014.

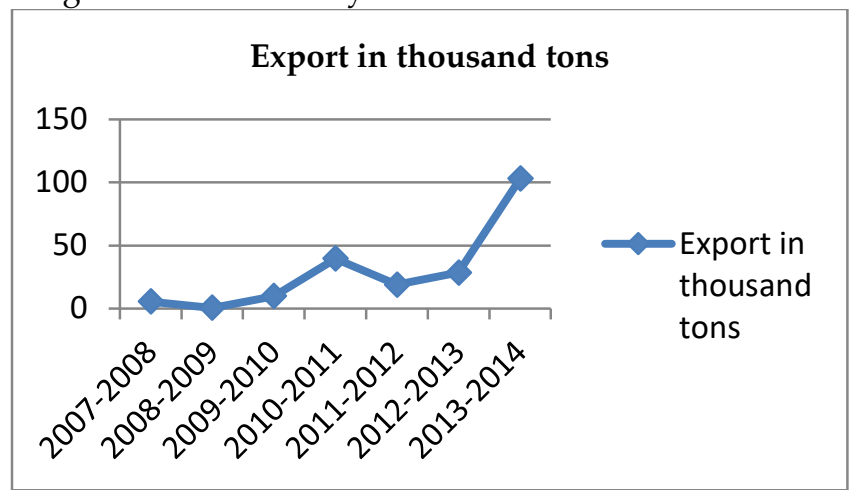

Fig: Export in thousand tons from 2007-2008 to 2013-2014

\section{Reasons behind the increase of exportation of potato} From our secondary data source DAE we got some reasons behind the increase of potato exportation which are given below:

- Low prices in the domestic market were one of the main factors behind the rising exports.

- Currently, exporters get 20 percent cash an incentive which is another factor behind rising exports.

- Potato exports have started rising since fiscal 2009-2010, mainly to cater to the demands of Bangladeshi migrants in Malaysia, Singapore and the Middle East.

\section{Relationship between Production and Export}

Relationship between production and export can be shown by the following table:

\section{Correlations}

\begin{tabular}{|c|c|c|c|}
\hline & & Production & Export \\
\hline production & $\begin{array}{l}\text { Pearson Correlation } \\
\text { Sig. (2-tailed) } \\
\mathrm{N}\end{array}$ & 1 & $\begin{array}{l}.770 \\
.127 \\
5 \\
\end{array}$ \\
\hline export & $\begin{array}{l}\text { Pearson Correlation } \\
\text { Sig. (2-tailed) } \\
\text { N }\end{array}$ & $\begin{array}{l}.770 \\
.127 \\
5\end{array}$ & 5 \\
\hline
\end{tabular}

Here we found that the coefficient of correlation between production and export is 0.77 which shows that there exits a strong positive correlation between these two variables production and export.

\section{Linear Regression Model}

Here to establish a linear regression model we can consider export as our dependent variable which depends on the production of potato. Hence our model is:

$$
Y-\bar{Y}=b(X-\bar{X})
$$

Here $b$ is our regression coefficient.

Model Summary
\begin{tabular}{|c|c|c|c|c|c|c|c|c|c|}
\hline Model & $\mathrm{R}$ & $\mathrm{R}$ \\
Square & $\begin{array}{c}\text { Adjusted } \\
\mathrm{R} \\
\text { Square }\end{array}$ & $\begin{array}{c}\text { Std. } \\
\text { Error } \\
\text { of the } \\
\text { Estimate }\end{array}$ & $\begin{array}{c}\text { R Square } \\
\text { Change }\end{array}$ & $\begin{array}{c}\mathrm{F} \\
\text { Change }\end{array}$ & df1 & df2 & $\begin{array}{c}\text { Sig. F } \\
\text { Change }\end{array}$ \\
\hline 1 & $.770 a$ & .593 & .458 & 11.30011 & .593 & 4.379 & 1 & 3 & .127 \\
\hline
\end{tabular}

a. Predictors: (Constant), production

Here $\mathrm{R}^{2}=.593$ for this model which represents the amount of variance in the criterion variable that is explained by the model. To express this value as a percentage, we multiply this value by 100 (which will tell us the percentage of variation in the criterion variable that can be explained by the model that is $59 \%$ variation of $Y$ can be explained by $X$.

\section{Estimates of potato per division}

Table 3: Estimates of potato, 2012-2013 (per division) \begin{tabular}{|l|l|l|l|l|l|}
\hline Division Chittagong Sylhet Dhaka & Barisal Khulna Rajshahi Rangpur \\
\hline
\end{tabular} \begin{tabular}{|l|l|l|l|l|l|l|l|}
\hline $\begin{array}{l}\text { Estimates } \\
\text { in .ton) }\end{array}$ & 584091 & 45766 & 1544198 & 118306 & 272529 & 2912087 & 3126142 \\
\hline
\end{tabular}

Source: Bangladesh Bureau of Statistics

We can graphically represent the above data below:

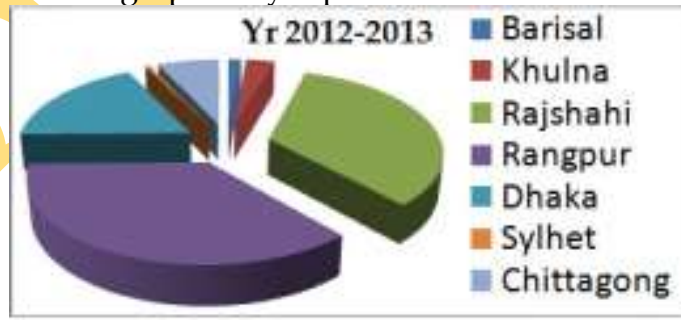

Fig: Estimation of potato per division (2012-2013)

Table 4: Estimates of potato, 2013-2014 (per division)

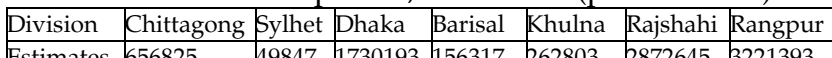
\begin{tabular}{|l|l|l|l|l|l|l|l|}
\hline $\begin{array}{l}\text { Estimates } \\
\text { (in M.ton) }\end{array}$ & 656825 & 49847 & 1730193 & 156317 & 262803 & 2872645 & 3221393 \\
\hline
\end{tabular}

Source: Bangladesh Bureau of statistics

Again we can represent the above data by a pie-chart below:

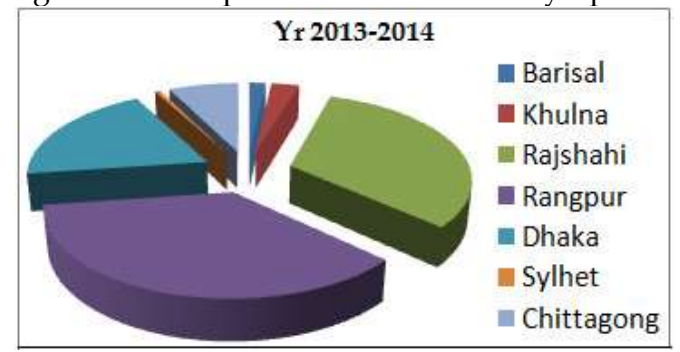

Fig: Estimation of potato per division (2012-2013)

The bar diagram shows us that in every division estimates of potato has increased in comparison to fiscal year 2012-2013 and 2013-2014. 
Estimate of Popato Production (in M. Ton)

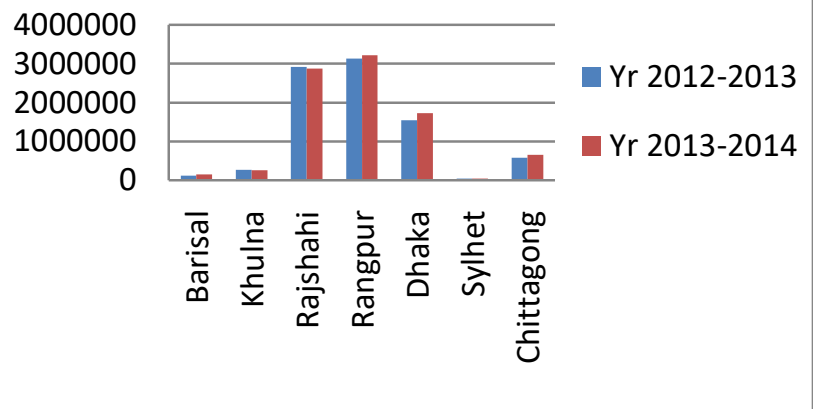

Fig: comparison of estimation between two fiscal years

\section{ReCOMmEndATIONS}

As discussed previously, our primary data showed some problems that our farmers usually face in their cultivation and production. Here are few important recommendations basing on the statements of the farmers:

- To reduce the cost of seed, it will be necessary to produce sufficient quality seeds locally and make them available to the farmers in time at a reasonable price.

- Development of market infrastructures such as road communication and transport should be increased, because farmers get higher price at market than home.

- Government should reduce the pesticide and insecticide price.

- The awareness of the farmers needs to be increased. They may be provided adequate training so that they can produce potatoes properly.

- Modern technology should be undertaken for better labor cost control.

- Government should take necessary steps so that the market price of potato remains uniform all round the year and all over the country. This may be possible through price control mechanism of the government.

- Agricultural credit facilities to be ensured easily.

\section{CONCLUSION}

In Southeast Asia the potato is an important vegetable in diet diversification and an anchor in intensive coolweather horticulture systems. The potato in these countries fills a role in diet diversification and improved nutrition. Bangladesh is the third largest potato producer in Asia and is among the top 10 of the potato producing countries (source: The Daily Prothom-Alo) of the world. It ranks third in area acreage after rice and wheat and is cultivated in almost all agro-ecological regions of Bangladesh. In addition, potato ranks second after rice in production in Bangladesh. From our data analysis, we found that in the context of production and export potato has a great prospect in Bangladesh. However, it is a matter of great regret that our farmers fail to get back even their production cost. Cost of productions becomes higher, but the price of potato becomes lower at the time of harvest. So, farmers become looser. Most of the potato farmers have failed to get back even 30 percent of their investment in the current season, which has created a shocking situation for them. Again cold storage charge is Tk. 4.2-4.5 per $\mathrm{kg}$ across the country which is a very high rate, on the other hand nearly 420 cold storages across the country can store 3.6 million tons of potato, which is 44 percent of the total production. Dissemination of market information should be increased so that farmers can get the fair price of the potato. Major problem faced by the potato farmers were lower price of potato during harvesting period, price fluctuation, shortage of capital, high charge of cold storage, lack of good quality seed, perishability of potato, poor storage facility, higher price of inputs and lack of marketing facility etc. Proper steps should be postulated by Government to puzzle out this problem. The determinations of the study will generate basic economic data on the production practices of potato. At long last it will be helpful to the planners and policy makers in contriving micro or macro level policy for the enlargement of potato production in the country. Potato farming is assuming a greater dimension, however bringing pressure on the government to expand its use as alternative food in the domestic sector as well as to explore it for greater export markets in overseas trade.

\section{REFERENCES}

Amare, B., Abay, F., \& Tsehaye, Y. (2015). Evaluation of Sweet Potato (Ipomea batata 1.) Varieties for Total Storage Root Yield in South and South East Zones of Tigray, Ethiopia. American Journal Of Trade And Policy, 1(3), 27-32. Retrieved from http://journals.abc.us.org/index.php/ajtp/article/view $/ 3.4 \% 281 \% 29$

Amare, B., Abay, F., \& Tsehaye, Y. (2015). Evaluation of Sweet Potato (Ipomea batata 1.) Varieties for Total Storage Root Yield in South and South East Zones of Tigray, Ethiopia. American Journal Of Trade And Policy, 1(3), 27-32. Retrieved from http://journals.abc.us.org/index.php/ajtp/article/vi ew $/ 3.4 \% 281 \% 29$

Araya, A., Girma, A., \& Getachew, F. (2015). Exploring Impacts of Climate Change on Maize Yield in Two Contrasting AgroEcologies of Ethiopia. Asian Journal Of Applied Science And Engineering, 4(1), 27-37. Retrieved from http://journals.abc.us.org/index.php/ajase/article/view/Araya

BARI Annual Report. 2009. Training and Communication Wing, Gazipur, Pp. 29-35

Challenges of Potato Cultivation In Bangladesh And Developing Digital Databases Of Potato. Issn 0258-7122 Bangladesh J. Agril. Res. 35(3) : 453-463, September 2010,

Chowdhury, M., Azam, M., \& Islam, S. (2015). Problems and Prospects of SME Financing in Bangladesh. Asian Business Review, 2(2), 51-58. Retrieved from http://journals.abc.us.org/index.php/abr/article/vi ew/4.8Chowdhury

DAE. 2009. Department Of Agriculture Extension, Ministry Of Agriculture, Khamarbari, Farm Gate, Dhaka.

Farmer's Profitability of Potato Cultivation at Rangpur District: The Socio-Economic Context Of Bangladesh Abu Zafar Ahmed Mukul1, Shah Johir Rayhan1, Mohammad Masudul Hassan2, * 
Faruk, M. (2015). The Effect of FDI to Accelerate the Economic Growth of Bangladesh and Some Problems \& Prospects of FDI. Asian Business Review, 2(2), 37-43. Retrieved from http://journals.abc.us.org/index.php/abr/article/view/Faruk

Http: / /Cipotato.Org/Press-Room/Blogs/201cchallenges-ToSustainable-Potato-Production-In-A-Changing-Climate-AResearch-Perspective201d.

Http:/ /Www.Academia.Edu/11130218/Country_Report_On_ Potato_Production_Status_Of_Bangladesh

http:/ /www.fao.org/docrep/010/i0200e/I0200E06.htm

Islam, K. (2015). Foreign Direct Investment (FDI) in Bangladesh: Prospects and Challenges and Its Impact on Economy. Asian Business Review, 4(1), 24-36. Retrieved from http://journals.abc.us.org/index.php/abr/article/view/Islam

Kamran, M., \& Shamshad, T. (2014). Impacts of Hill Torrents' Management on Socio-Economic Conditions of Arid Land Farmers: a Case Study of Tehsil D.G. Khan. Asian Journal Of Humanity, Art And Literature, 1(3), 155-162. Retrieved from http://journals.abc.us.org/index.php/ajhal/article/ view/Kamran

Katsaruware, R., \& Gwembire, J. (2014). Float Trays as an Alternative to Methyl Bromide in Tobacco Production in Hurungwe District, Zimbabwe. Asian Journal Of Applied Science And Engineering, 3(2), 119-128. Retrieved fromhttp://journals.abc.us.org/index.php/ajase/article/v iew $/ 6.9 \% 28 \mathrm{k} \% 29$
Mekonen, M., Tesfaye, K., \& Bayu, W. (2013). Soil Drainage and Nutrient Management to Improve Productivity of Waterlogged Vertisols for Small-scale Farmers. Engineering International, 1(2), 27-39. Retrieved from http://journals.abc.us.org/index.php/ei/article/view/2.3\%281\%29

Miah, M. (2013). Enhancing Food Security through Acclimatized Species Domestication in the Haor Region. ABC Journal Of Advanced Research, 2(1), 49-65. Retrieved fromhttp://journals.abc.us.org/index.php/abcjar/article/ view/3.6

Nahar, K. (2012). Biogas Production from Water Hyacinth (Eichhornia Crassipes). Asian Journal Of Applied Science And Engineering, 1(1), 9-13. Retrieved from http://journals.abc.us.org/index.php/ajase/article/view/1.1.12

Njoroge, P., Shibairo, S., Githiri, S., \& Mburu, M. (2014). Effects of Nitrogen Application on Growth and Yield of Snowpeas (Pisum sativum). Asian Journal Of Applied Science And Engineering, 3(1), 35-43. Retrieved from http://journals.abc.us.org/index.php/ajase/article/view/Njoroge

Shakil, M., Tasnia, M., Munim, Z., \& Mehedi, M. (2015). Mushroom as a Mechanism to Alleviate Poverty, Unemployment and Malnutrition. Asian Business Review, 4(3), 31-34. Retrieved from http://journals.abc.us.org/index.php/abr/article/view/Shakil

The Financial Express, 29-01-2014, "BD Potato Lowest Price in Globe". 